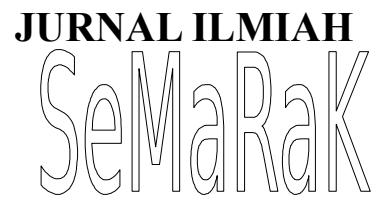

P-ISSN 2615-6849, E-ISSN 2622-3686

Jurnal Semarak,Vol. 2,No.3, Oktober 2019, Hal (10- 30)

(a) Prodi Manajemen Fakultas Ekonomi Universitas Pamulang

\title{
PENGARUH KESELAMATAN KERJA DAN PELATIHAN TERHADAP KINERJA KARYAWAN PADA PT. AEROFOOD CATERING SERVICE DIVISI LAUNDRY TANGERANG
}

\author{
Rahmi Hermawati, Mariza \\ Dosen Fakultas Ekonomi Universitas Pamulang
}

Email :dosen00817@,unpam.ac.id atau rahmi_herma@yahoo.com

This study shall aim inestablishing the effect of work safety as well as the training on performance at PT Aerofood Catering ServiceLaundry Division, to specify the effect of training on the performance of employees of PT Aerofood Catering Service Laundry division, and to find out how much influence work safety and training shall impact on performance of employees of PT Aerofood Catering Service Laundry division collectively.

The population and sample of this study shall be 50 respondents who are employees of PT Aerofood Catering Service Laundry division. The variables in this study consist of Occupational Safety (X1) and Training (X2) as independent variables while Employee Performance (Y) as the dependent variable. The method of data collecting shall be using observation, questionnaires and interviews. Data analysis shall be using multiple linear regression, analysis of product moment coefficient test, Test coefficient of determination ( $k d$ ), significance test both partially (t test) and simultaneously / together (test f).

In accordance with the results of the study, the variable Safety at PT Aerofood Catering Service Laundry division which shall be categorized as Good while Training variable at PT Aerofood Catering Service Laundry division shall be categorized as Good and Employee Performance variable at PT Aerofood Catering Service Laundry division shall be categorized as GOOD. There is a positive influence between Work Safety and Training on Employee Performance with a regression value of 5,029X1 and 2,107X2. The value of the correlation coefficient (r) shall be 0.997. This means that work safety and training variables have a very strong relationship to employee performance and the value of determination (Kd) of 0.998, It can be concluded that work safety (X1) and training (X2) on employee performance (Y) shall be $99.8 \%$ while the rest of $0,4 \%$ shall be influenced by other factors. Obtained Work Safety (X1) t value or $t$ table (5.629> 1.677), this is also reinforced by a significance value of $0.000<0.05$, it can be said to be significant. This means that Ho shall be rejected and H1shall be accepted, which means, there is a positive and significant influence between training on employee performance. While the value of $t$ count Training $(X 2)>t$ table or $(25,666>1,677)$, this is also reinforced with a significance value of 0,000 $<0,05$, so it can be said to be significant. This means that Ho is rejected and H1 is accepted, which means there is a positive and significant influence between training on employee performance. The value of $F$ count $>F$ table or $(5886.67>2,800)$, this shall be also reinforced by a significance value of $0,000<0,05$, so that it can be said to be significant. This means that Ho shall be rejected and Ha shall be training on performance.

Keywords: Work Safety, Training and Performance

I.PENDAHULUAN
A. Latar Belakang 
Suatu program yang diupayakan dalam rangka mencegah timbulnya kecelakaan akibat kerja dan penyakit akibat kerja di tempat kerja dinamakan Prgram Keselamatan dan Kesehatan Tujuannya untuk menciptakan tempat kerja yang nyaman dan sehat sehingga dapat menekan serendah mungkin risiko terjadinya kecelakaan dan penyakit akibat kerja (occupational desease). Peningkatan kesadaran keselamatan dan kesehatan kerja (K3) diharapkan berdampak pada penurunan angka kecelakaan kerja di perusahaan.Dalam upaya menurunkan tingkat kecelakaan kerja dan menciptakan kondisi dan lingkungan kerja yang aman dan nyaman bagi karyawan, maka perusahaan perlu melaksanakan pogram Keselamatan dan Kesehatan Kerja (K3). Jika seorang karyawan mengalami kecelakaan yang disebabkan oleh rasa tidak aman dan nyaman dalam melakukan atau menja-lankan pekerjaannya, maka tidak hanya merugikan pribadi pekerja itu sendiri tapi juga perusahaan tempat ia bekerja. Beberapa faktor dan kondisi yang menyebabkan terjadinya kecelakaan kerja, diantaranya adalah kurangnya perawatan terhadap alat-alat kerja,penggunaan peralatan kerja yang tidak sesuai dengan standar prosedur yang ada, dan peralatan kerja yang sudah tidak layak pakai. Untuk mengurangi risiko kecelakaan kerja sebaiknya perusahaan menerapkan program Keselamatan dan Kesehatan Kerja (K3),misalkan mengerti dan memahami prosedur melakukan pekerjaan. Sadar bahwa disekitar mereka ada hazard atau bahya yang mengintai.

Perhatian terhadap kesehatan pekerjaan pada mulanya lebih menekankan pada masalah keselamatan kerja yaitu kurangnya Alat Pelindung Diri (APD) atau Personnel Protective Equipment (PPE) dari pekerjaan dan juga kerugian atau luka yang disebabkan oleh kecelakaan kerja. Kemudian seiring dengan perkembangan industri, perusahaan mulai memperhatikan kesehatan pekerja dalam arti luas yaitu terbebasnya pekerjaan dari kesakitan fisik maupun psikis. Besarnya potensi kecelakaan kerja tergantung dari jenis tata ruang dan lingkungan bangunan serta kualitas manajemen dan tenaga-tenaga pelaksana. Kecelakaan kerja tersebut mengakibatkan banyak pekerja meninggal dan cacat, sehingga tidak bisa lagi melakukan pekerjaan. Dampak kondisi fisik yang menurun atau dan ketidakmampuan untuk bekerja, produktivitas pun akan berkurang dan kinerja karyawan menurun akibat terjadinya kecelakaan kerja.Hal ini tentunya dapat berakibat pada kematian, atau karyawan dapat mengalami cacat atau sakit untuk sementara atau selamanya 


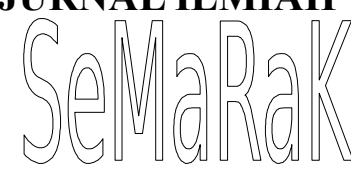

sehingga karyawan yang bersangkutan tidak mampu lagi bekerja dengan baik Dengan demikian tingkat produktivitas kerjanya akan mengalami penurunan dibanding waktu sehat. Oleh sebab itu perlu sistem pemberian kompensasi yang tepat terhadap kecelakaan dan penyakit akibat kerja, karena itu akan menumbuhkan rasa aman dan semangat kerja untuk meningkatkan kinerja karyawan.

Menurut Triton PB (2010 :18) pelatihan bertujuan untuk memperbaiki bagaimana karyawan dapat menguasai berbagai keterampilan dan tata cara pelaksanaan kerja tertentu untuk kebutuhan sekarang, sedangkan pengembangan bertujuan untuk menyiapkan pe-gawainya siap memangku jabatan tertentu di masa yang akan datang. Pengembangan bersifat lebih luas karena menyangkut banyak aspek seperti peningkatan dalam keilmuan, pengentahuan, kemampuan, sikap dan kepribadian. Pelaksanaan Program pelatihan dan pengembangan di suatu organisasi bertujuan untuk menutupi kekurangan kecakapan karyawan dengan permintaan jabatan,dan juga dapat meningkatkan efisiensi dan efektivitas kerja karyawan dalam pencapaian sasaran. Rendahnya kesadaran akan keselamatan kerja hendaknya karyawan di beri pelatihan agar kinerja karyawan sesuai dengan ekspektasi perusahaan. Agar pelaksanaan program pelatihan tidak siasia, maka sebaiknya perlu diidentifi-kasi mengenai kebutuhan, tujuan, sasaran, metode serta isi prinsip pelatihan atau pembelajaran yang akan diberikan.

Berdasarkan hal tesebut di atas, ma-ka PT. Aerofood ACS Unit Laundry (anak perusahaan dari PT. Aerofood ACS Indonesia), yang bergerak dalam bidang jasa pelayanan laundry untuk maskapai penerbangan Garuda Indonesia dan Foreign Airlines, berupaya untuk selalu memperhatikan $\quad \mathrm{K} 3 \quad$ bagi karyawannya.Pelaksanaan program keselamatan dan kesehatan kerja bagi karyawan penting karena bertujuan untuk menciptakan sistem keselamatan kerja dengan meli-batkan unsur manajemen, tenaga kerja, kondisi dan lingkungan kerja yang terin-tegrasi dalam rangka mengurangi kece-lakaan.

Berikut data kelengkapan keselamatan kerja di perusahaan :

Tabel 1.1

Kondisi Penggunaan APD

\begin{tabular}{|l|l|l|l|}
\hline No & Kelengkapan & \multicolumn{1}{|c|}{ Kondisi } & \multicolumn{1}{|c|}{ Keterangan } \\
\hline 1. & Masker & $\begin{array}{l}\text { Adanya karyawan yang tidak/ } \\
\text { jarang menggunakannya }\end{array}$ & $\begin{array}{l}\text { Bisa menyebabkan batuk dan } \\
\text { sesak nafas }\end{array}$ \\
\hline 2. & Safety Shoes & $\begin{array}{l}\text { Hampir seluruh karyawan tidak } \\
\text { memakai safety shoes }\end{array}$ & $\begin{array}{l}\text { Agar terhindar dari lantai licin } \\
\text { karena bahan- bahan chemical }\end{array}$ \\
\hline 3. & Helm & $\begin{array}{l}\text { Tidak pernah menaruhnya } \\
\text { kembali ketempat semula }\end{array}$ & $\begin{array}{l}\text { Agar terhindar dari barang- } \\
\text { barang besi }\end{array}$ \\
\hline 4. & Sarung tangan & $\begin{array}{l}\text { Bahan sarung tangan mudah } \\
\text { sobek }\end{array}$ & $\begin{array}{l}\text { Menyebabkan tangan mudah } \\
\text { terluka }\end{array}$ \\
\hline 5. & Pakaian Pelindung & $\begin{array}{l}\text { Kurangnya pakaian pelindung } \\
\text { yang disediakan perusahaan }\end{array}$ & Melindungi dari uap panas. \\
\hline
\end{tabular}

Sumber : Data Observasi PT Aerofood Catering

Berdasarkan tabel diatas menunjukkan bahwa masih kurangnya kesadaran ten- 


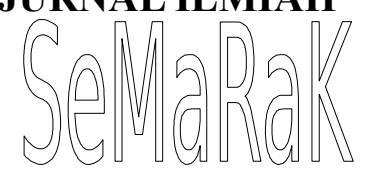

tang keselamatan kerja dan masih saja ada kecelakaan kerja yang seharusnya tingkat kecelakaan kerja adalah zero accident (tidak ada kecelakaan). Di dalam bekerja mereka masih belum menggunakan APD (Alat Pelindung Diri).

Tabel 1.2

Kondisi Penggunaan APD

\begin{tabular}{|c|c|l|l|l|}
\hline No & Tahun & $\begin{array}{c}\text { Akibat } \\
\text { kecelakaan }\end{array}$ & Keterangan & Jumlah \\
\hline 1 & 2015 & $\begin{array}{l}\text { Terpeleset karena } \\
\text { tergenangnya air }\end{array}$ & $\begin{array}{l}\text { Tidak memakai } \\
\text { sepatu safety }\end{array}$ & 1 orang \\
\hline 2 & 2016 & $\begin{array}{l}\text { Luka goresan } \\
\text { akibat kertas } \\
\text { alumunium foil }\end{array}$ & $\begin{array}{l}\text { Tidak memakai } \\
\text { sarung tangan }\end{array}$ & 2 orang \\
\hline 3 & 2017 & $\begin{array}{l}\text { Sesak nafas saat } \\
\text { berada di dalam } \\
\text { ruangan boiler }\end{array}$ & $\begin{array}{l}\text { Tidak memakai } \\
\text { masker }\end{array}$ & 1 orang \\
\hline
\end{tabular}

Sumber : Data Observasi PT Aerofood Catering

Tabel di atas menunjukkan kurangnya kesadaran karyawan akan APD sehingga menimbulkan kecelakaan kerja, Untuk mengurangi tingkat kecelakaan kerja di PT. Aerofood Catering Service divisi Laundry sudah melakukan pelatihan untuk keselamatan kerja yang dilakukan oleh HSE berikut data pelatihanya adalah:

Tabel 1.3

Data Pelatihan K3

\begin{tabular}{|c|c|c|c|c|c|}
\hline Tahun & $\begin{array}{c}\text { Materi } \\
\text { Pelatihan }\end{array}$ & $\begin{array}{c}\text { Jumlah } \\
\text { karyawan }\end{array}$ & $\begin{array}{c}\text { Karyawan } \\
\text { ikut Serta }\end{array}$ & $\begin{array}{c}\text { Karyawan } \\
\text { tidak ikut } \\
\text { Serta }\end{array}$ & Evaluasi \\
\hline 2015 & Basic HSE & 93 & 80 & 12 & \begin{tabular}{l} 
- Mengetahui apa itu HSE \\
\hline $\begin{array}{l}\text { - Mengethui penyebab } \\
\text { kecelekaan dan pencegahnya }\end{array}$
\end{tabular} \\
\hline 2016 & $\begin{array}{l}\text { Pencegahan } \\
\text { Bahaya } \\
\text { Kebakaran }\end{array}$ & 93 & 81 & 11 & $\begin{array}{l}\text { Mengetahui bahaya proteksi } \\
\text { kebakakaran }\end{array}$ \\
\hline $\begin{array}{l}\text { - Dapat menggunakan alat } \\
\text { pencegah kebakaran }\end{array}$ \\
\hline $\begin{array}{l}\text { - Meningkatkan drajat } \\
\text { kesehatan } \\
\text { Personal } \\
\text { Hygiene }\end{array}$ & 93 & 90 & 3 & $\begin{array}{l}\text { Memelihara kesehatan diri } \\
\text { Pencegahan penyakit }\end{array}$ \\
\hline
\end{tabular}

Sumber : Data Observasi PT Aerofood Catering

Berdasarkan data diatas terlihat bahwa pada tahun 2015, 206 dan 2017 target pelatihan untuk karyawan belum 100\%, yang artinya tidak semua karyawan mengikuti pelatihan K3 dan Personal Hygiene.

Dari data sebelumnya masih banyak karyawan yang belum sadar akan pentingnya menggunakan alat pelindung diri ( APD ). Hal ini di karenakan masih ada karyawanyang belum mengikuti pelatihan tentang K3. Terjadinya kecelakaan kerja dan dapat mempengaruhi produksi perusahaan sehingga kinerja yang kurang optimal. Banyak karyawan yang tidak masuk bekerja dikarenakan sakit karena terkontaminasi dengan udara kotor atau zat-zat kimia.

Tabel 1.4

Data Kehadiran

\begin{tabular}{|c|c|c|c|c|}
\hline \multirow{2}{*}{ Tahun } & \multicolumn{4}{|c|}{ Keterangan Absen } \\
\cline { 2 - 5 } & Sakit & Presentase & Izin & Presentase \\
\hline 2015 & 37 Orang & $61,70 \%$ & 30 Orang & $50 \%$ \\
\hline 2016 & 42 Orang & $70 \%$ & 35 Orang & $58.3 \%$ \\
\hline 2017 & 47 Orang & $78,30 \%$ & 44 Orang & $73,30 \%$ \\
\hline
\end{tabular}

Sumber : Data HRD PT Aerofood Catering Grafik Absen

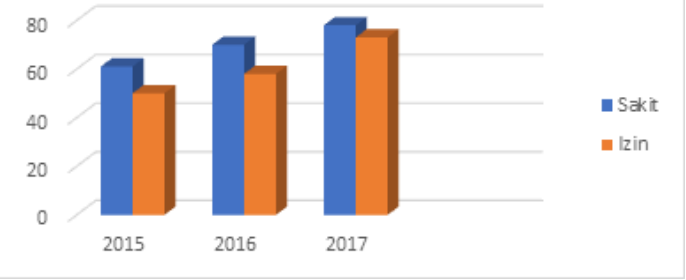

Gambar 1.1

Grafik Kehadiran

Dari data dan grafik diatas dapat kita lihat, tingkat tertinggi pada tahun 2017 tingkat absensi karyawan yang sakit sebanyak $78,3 \%$ atau setara 47 orang dan absensi izin sebanyak $73,3 \%$ atau setara 


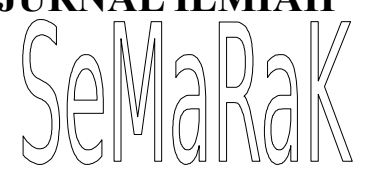

dengan 44 orang, jadi bisa dilihat tingkat absensi cenderung meningkat pada tahun 2017, karena tingkat abesensi yang masih tinggi.

Melihat begitu esensialnya keselamatan dan kesehatan kerja dalam pelatihan kinerja suatu perusahaan, maka penulis tertarik untuk melakukan penelitian yang berjudul "Pengaruh Keselamatan Kerja dan Pelatihan terhadap Kinerja Karyawan pada PT Aerofood Catering Service Divisi Laundry Tangerang”

\section{B. Identifikasi Masalah}

Berlandaskan latar belakang di atas, maka identifikasi masalah yang dapat penulis kemukakan adalah sebagai berikut :

1. Kurangnya perawatan terhadap perlengkapan kerja.

2. Ketidaksesuaian penggunaan peralatan kerja dengan prosedur.

3. Peralatan kerja yang sudah tidak layak pakai.

4. Rendahnya kesadaran tenaga kerja akan keselamatan kerja

5. Kurangnya pelatihan keselamatan kerja bagi karyawan

6. Kinerja yang kurang optimal

\section{Pembatasan Masalah}

Bertolak dari identifikasi masalah di atas maka pada penelitian ini dibatasi pada hal-hal sebagai berikut:

1. Menurut Mangkunegara (2013), keselamatan kerja menunjukkankondisi rasa aman atau selamat. terhindar dari penderitaan, kerusakan atau kerugian ditempat kerja.

2. Pelatihan dalam Manajemen Sumber Daya Manusia. Menurut Gomes (2003:197), pelatihan adalah setiap usaha untuk memperbaiki performansi pekerja pada suatu pekerjaan tertentu yang sedang menjadi tanggung jawabnya.

3. Kinerja adalah hasil atau tingkat keberhasilan seseorang secara keseluruhan selama periode tertentu di dalam melaksanakan tugas dibandingkan dengan berbagai kemungkinan, seperti standar kinerja, target atau sasaran yang telah disepakatain dan ditentukan sebelumnya. Menurut Robbins (2005) kinerja merupakan fungsi dari kemampuan, motivasi dan kesempatan. Kinerja $=\mathrm{f}$ (Ability $\mathrm{x}$ Motivation $\mathrm{x}$ Opportunity).

4. Objek penelitian ini adalah PT. Aerofood Catering Service beralamat di Jl.Iskandar Muda pergudangan bandara mas blok M1 Tangerang.

5. Penelitian dilaksanakan pada bulan Aguastus 2018 sampai Oktober 2018.

\section{Perumusan Masalah}

Pokok permasalahan yang dihadapi dalam penelitian ini adalah:

1. Seberapa besar pengaruh keselamatan kerja terhadap kinerja karyawan pada PT. Aerofood Catering Service Divisi Laundry Tangerang? 


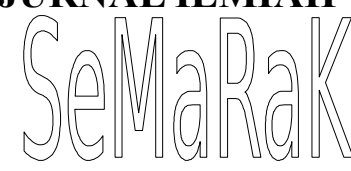

2. Seberapa besar pengaruh pelatihan terhadap kinerja karyawan pada PT. Aerofood Catering Service Divisi Laundry Tangerang ?

3. Seberapa besar pengaruh Keselamatan kerja dan pelatihan terhadap kinerja karyawan PT. Aerofood Catering Service Divisi Laundry Tangerang secara simultan?

\section{E. Tujuan dan Manfaat Penelitian}

\section{Tujuan Penelitian}

Berdasarkan pada rumusan masalah yang telah dipaparkan diatas, maka tujuan penelitian ini adalah :

a. Untuk mengetahui seberapa besar pengaruh keselamatan kerja terhadap kinerja karyawan PT. Aerofood Catering Service Divisi Laundry Tangerang.

b. Untuk mengetahui seberapa besar pengaruh pelatihan terhadap kinerja karyawan PT.Aerofood Catering Service Divisi Laundry Tangerang.

c. Untuk mengetahui seberapa besar pengaruh keselamatan kerja dan pelatihan terhadap kinerja karyawan PT. Aerofood Catering Service Divisi Laundry Tangerang

\section{Manfaat Penelitian}

a. Teoritis

1) Bagi Peneliti

Memberikan pemahaman pentingnya dalam penggunaan APD bagi para pekerja bagian produksi di PT. Aerofood Catering Service divisi
Laundry sehingga tercapainya keselamatan kerja dalam kegiatan kerja di perusahaan tersebut.

2) Bagi Universitas

Memberikan gambaran kenyataan di lapangan serta memberikan wawasan bagi para pembaca dan rekan mahasiswa untuk mngembangkan ilmu pengetahuan mengenai sumber daya manusia, khususnya mengenai $\mathrm{K} 3$, Pelatihan dan Kinerja.

b. Praktis

Bagi Perusahaan

Memberikan gambaran suatu keselarasan antara para pekerja bagian produksi dengan perusahaan untuk tercapainya tujuan yang diinginkan bersama dalam membuat bahan-bahan yang akan diproduksinya.

\section{F. Kerangka Berpikir}

Kerangka berfikir yang baik akan menjelaskan secara teoritis pertautan antar variabel yang akan diteliti,sehingga secara teoritis perlu dijelaskan hubungan antar variabel independen dan dependen. Berikut ini penulis menyajikan kerangka berfikir yang menempuh cara berfikir rasional tentang keselamatan kerja dan pelatihan terhadap kinerja, melalui indikator-indikator sebagai berikut: 

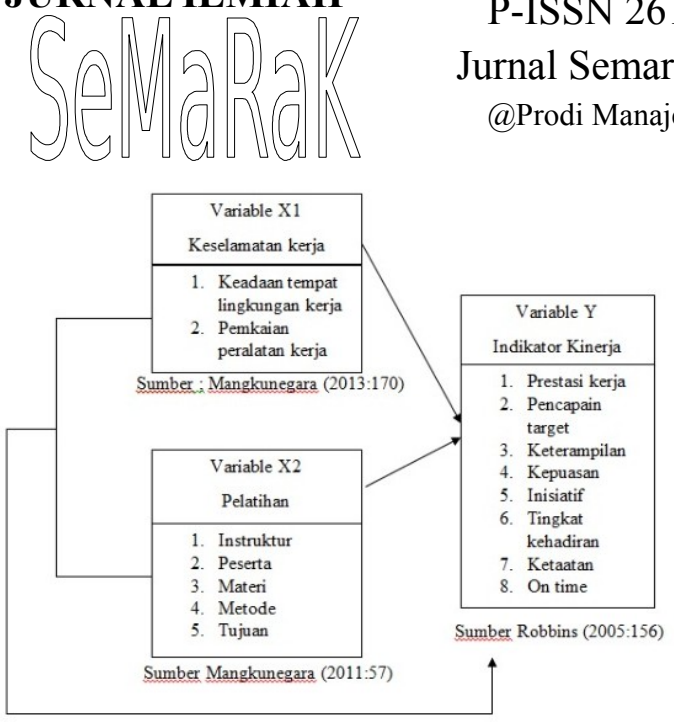

Gambar 1.2

Kerangka Berfikir

\section{G. Hipotesis}

Hipotesis merupakan suau kesimpulan yang bersifat sementara terhadap permasalahan peneliti sampai terbukti melalui data yang terkumpul. Dari rumusan masalah di atas makahipotesis penelitiannya adalah:

- $\mathrm{Ha}_{1}=$ Terdapat pengaruh yang positif antara keselamatan kerja terhadap kinerja karyawan PT Aerofood Catering Service divisi Laudry Tangerang.

- $\mathrm{Ha}_{2}=$ Terdapat pengaruh yang positif antara pelatihan terhadap kinerja karyawan pada PT Aerofood Catering service divisi laundry

- $\mathrm{Ha}_{3}=$ Terdapat pengaruh yang positif antara keselamatan kerja dan pelatihan terhadap kinerja karyawan pada PT Aerofood Catering Service divisi Laundry Tangerang secara simultan.

\section{II.LANDASAN TEORI}

\section{A. Manajemen}

Drucker (2011:10) mengungkapkan bahwa manajemen adalah tentang manusia.Tugasnya adalah membuat orang mampu melakukan kinerja bersama, untuk membuat kekuatan mereka lebih efektif dan kelemahan mereka tidak relevan.

Menurut Terry yang dikutip dalam Hasibuan (2017:1) mengemukakan bahwa "manajemen adalah suatu proses yang khas, yang terdiri dari tindakan perencanaan, pengorganisasian, penggetakan, dan pengendalian untuk menetukan mencapai sasaran yang telah ditentukan melalui pemanfaatan sumber daya manusia maupun sumber daya lainnya."

\section{B. Manajemen SDM}

Kesuksesan suatu organisasi dikarenakan peran sumber daya manusia yang optimal. Organissi menyakini bahwa unsur manusia merupakan suatu keunggulan bersaing (competitive advantage). SDMmerencanakan sautu strategiyang tepat dalampencapaian tujuan organisasi. Dengan demikian sumber daya manusia merupakan faktor utama yang paling vital bagi organisasi.

Menurut Hasibuan (2017:244) Sumber daya manusia adalah kemampuan terpadu dari pola pikir dan fisik yang dimiliki seseorang. Pelaku dan sifatnya dilakukan oleh keturunan dan lingkungannya, sedangkan prestasi kerjanya dimoti- 
vasi oleh keinginan untuk memenuhi kepuasannya.

\section{Keselamatan Kerja}

\section{Pengertian Keselamatan Kerja}

Menurut Megginson yang dikutip oleh Mangkunegara(2013:161) mengemukakan bawah keselamatan kerja menunjukan kondisi yang aman atau selamat dari penderitaan kerusakan, kerugian ditempat kerja.

Menurut Darsono dan Tjatjuk (2011:55) dalam melaksanakan pekerjaan karyawan harus dijaga keselamatannya agar kinerja mereka meningkat . menjaga keselamatan berarti menjaga jasmani maupun rohani dan menjaga agar tidak terjadi kecelakaan dalam bekerja. Karyawan yang sehat dan selamat dalam bekerja berdampak positif bagi perusahaan, kinerjameningkat, laba meningkat, perusahaa dapat meluaskan usahanya, pemilik modal dapat memperoleh hasil yang tinggi dan meningkat kesejahteraan karyawan.

Menurut Al-Fajar dan Heru (2010:204) menyatakan bawah keselamatan kerja karyawan menunjukan pada kondisi fisiologi fisik dan psikologi tenaga kerja yang diakibatkan dari lingkungan peru-sahaan. Apabila sebuah perusahaan melaksanakan tindakantindakan kesela-matan yang efektif, maka akan mengurangi cedera atau penyakit akibat kerja yang diaalamikaryawan.

Dari beberapa definisi para ahli diatas, penulis menyimpulkan bawah keselamatan kerja adalah suatu upaya menjaga keselamatan diri dalam bekerja untuk meminilkan resiko kecelakaan kerja.

\section{Indikator Keselamatan Kerja}

Keselamatan kerja merupakan suatu kondisi yang aman atau terhindar dari penderitaan atau kerugian yang dialami di tempat kerja. Adapun indikator keselamatan kerja menurutMangkunegara (2013:170) adalah sebagai berikut :

a. Keadaan tempat lingkungan kerja

1) Penyusunan dan penyimpanan barang-barangyang berbahaya yang kurang di perhitungkan keamananya.

2) Ruang kerja yang yang terlalu padat.

3) Pembuangan limbah atau kotoran yang tidak pada tempatnya.

b. Pemakain peralatan kerja

1) Pengaman peralatan kerja yang sudah usang atau rusak.

2) Penggunaan mesin, alat elektronik tanpa pengaman yang baik pengaturan penerangan.

\section{Pelatihan}

\section{Pengertian Pelatihan}

Menurut Bernandian dan Russel dalam Gomes (2003:197), pelatihan adalah se- 


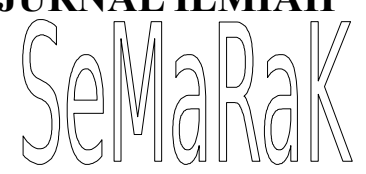

tiap usaha untuk memperbaiki performa pekerja terhadap pekerjaan tertentu yang menjadi tanggung jawabnya.

Pelatihan yang dirancang sebaiknya mewujudkan tujuan-tujuan organisasi, yang pada waktunya bersamaan juga mewujudkan tujuan-tujuan para karyawan secara perorangan.

\section{Indikator-Indikator Pelatihan}

Ada beberapa indicator yang digunakan untuk mengukur pelatihan menurut Mangkunegara (2013:57) adalah:

\section{a. Instruktur}

Pendidikan lebih mengutamakan pada peningkatan kemampuan individu melalui jalur formal dengan jangka waktu yang panjang, guna memaksimalkan penyampaian materi kepada peserta pelatihan.Pengu-saan materi sangat penting untuk mela-kukan proses pelatihan dengan baik sehingga penyampaian meteri kepada para peserta pelatihan mudah dipahami.

\section{b. Peserta}

Sebelum melaksanakan program pelatihan terlebih dahulu perusahaan melakukan proses seleksi, yaitu pemilihan sekelompok orang yang paling memenuhi persyaratan untuk posisi yang available.

\section{c. Materi}

Materi yang diberikan dalam program pelatihan akan lebih efektif apabila sesuai dengan komponen peserta sehingga pro- gram pelatihan tersebut dapat menambah kemampuan peserta.

yang diberikan kepada peserta harus tepat sasaran sehingga mampu mendorong peserta pelatihan untuk mengaplikasikan materi yang telah disampaikan dalam melaksanakan pekerjanyaMateri yang diberikan kepada peserta harus tepat sasaran sehingga mampu

\section{d. Metode}

Metode penyampaian sesuai dengan materi yang hendak disampaikan sehingga diharapkan peserta pelatihan dapat menangkap maksud dan tujuan pelatihanyang disampaikan oleh instruktrur.

\section{e. Tujuan}

Diselenggarakannya pelatihan, hasil yang diharapkan dapat meningkatkan keterampilan/skill, pengetahuan dan perilaku pesertanya.

\section{E. Kinerja}

\section{Pengertian Kinerja}

Kinerja akan selalu menjadi isu aktual dalam organisasi karena apapun organisasinya kinerja merupakan pernyataan kunci terhadap efektivitas atau keberhasilan dari suatu organisasi atau perusahaan.

Menurut Handoko (2014:135), "penilaian kinerja adalah proses melalui mana organisasi-organisasi mengevaluasi menilai prestasi kerja karyawan". Pada 


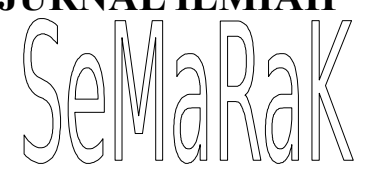

saat melakukan penilaian kerja karyawan, seorang pemimpin harus mengetahui bagaimana hal yang perlu dijadikan bahan pemikiran dalam upaya meningkatkan kinerja karyawan merupakan suatu evaluasi terhadap penampilan kinerja karyawan.

\section{Indikator Kinerja}

Pada dasarnya indikator kerja digunakan secara bergantian dengan ukuran kinerja, tetapi banyak pula yang membedakanya. Dalam hal ini penulis menemukan beberapa indikator untuk mengukur variable kinerja menurut Robbins (2005:156), diantaranya:

\section{a. Prestasi Kerja}

Ketika hasil tugas seseorang sulit ditentukan, perusahaan dapat mengevaluasi dari perilaku (hasil kerja) karyawan tersebut yang berhubungan dengan tugasnya.

\section{b. Pencapaian Target}

Pencapaian target menjadi faktor penentuyang harus dievaluasi.Dengan hasil pencapaian target dapat diketahuikapasitas dan kemampuan karyawan dalam menyelesaikan beban pekerjaanya.

\section{c. Keterampilan}

Meliputi sekumpulan yang bersifat teknis, antara pribadi atau berorientasi bisnis.

\section{d. Kepuasan}

Yaitu kualitas kerja yang dicapai berdasarkan syarat-syarat kesesuaian dan kesiapan karyawan.

\section{e. Inisiatif}

Yaitu semangat untuk melaksanakan tugas atau pekerjaan baru dan dalam memperluas tanggung-jawab seseorang.

\section{f. Tingkat Kehadiran}

Tingkat kehadiran menjadi salah satu tolak ukur untuk mengetahui tingkat disiplin karyawan. Semakin tinggi kehadirannya atau rendah kemangkiran, maka karyawan tersebut telah memiliki disiplin kerja yang tinggi yang berdampak pada kinerja karyawan tersebut.

\section{g. Ketaatan}

Ketaatan yaitu kesadaran dan kesedian dalam hal penyelesain kerja.

\section{i. Ketepatan Waktu}

Kuantitas hasil kerja yang didapat dalam suatu periode waktu yang telah ditentukan oleh manajer atau perusahaan.

\section{G.Penelitian Terdahulu}

Dalam melaksanakan penelitian tidak terlepas dari kajian penelitian sebelumnya sebagai landasan dan acuan arah dari penelitian ini.

\section{III.METODOLOGIPENELITIAN}

\section{A. Ruang Lingkup Penelitian}

Penelitian dilaksanakan di PT Aerofood

Catering Service divis Laundry, Jl. Marsekal Surya Darma Blok M No. 1 Tangerang, Penelitian dilakukan Bulan 


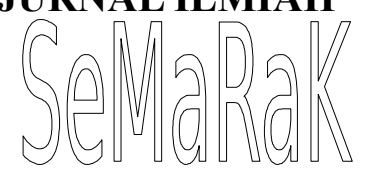

Juni-Oktober 2018. Jenis penelitian yang digunakan adalah kausalitas yakni tipe penelitian terkait dengan karakteristik masalah berupa hubungan sebab akibat antar dua variabel atau lebih. Penelitian ini ditujukan untuk mengetahui seberapa besar pengaruh antara variabel keselamatan kerja , pelatihan dan kinerja..

\section{B. Populasi dan Sampel}

\section{Populasi}

Definisi populasi adalah wilayah generalisasi yang terdiri atas obyek atau subyek yang mempunyai kualitas dan karakteristik yang ditetapkan oleh peneliti untuk dipelajari dan kemudian ditarik kesimpulannya

(Sugiyono, 2013:80).Populasi penelitian ini adalah 50 orang, sejumlah karyawan pada PT Aerofood Catering Service Divisi Laundry Tangerang.

\section{Sampel}

Peneliti menggunakan sampel jenuh dalam penelitian ini.Sampling jenuh adalah teknik penentuan sampel bila semua anggota populasi digunakan sebagai sampel (Sugiyono, 2013:124).

Dikarenakan hal tersebut, maka jumlah sampel yang digunakan adalah 50 orang sama dengan total populasi.

\section{Sumber Data}

Keterangan atau informasi yang di dapat kebenaran dan kenyataannya, dapat dijadikan kajian analisis atau kesimpulan dalam sebuah analisis atau kesimpulan dalam sebuah penelitian.

Agar peneliti mendapatkan data dan informasi yang akurat dan objektif, maka dilakukan teknik pengumpulan data, sebagai berikut:

\section{Data Primer}

Penelitian ini menggunakan data primer yaitu sumber data penelitian yang diperoleh secara langsung dari sumber asli (sampel) yang memberikan data kepada pengumpul data Sugiyono (2013:137).

Data primer yang penulis gunakan adalah kuesioner dengan skala likert yang didistribusikan kepada responden.

\section{Data Sekunder}

Data sekunder adalah data tidak langsung yang didapat melalui pihak ketiga. Peneliti dapat memperoleh data informasi yang mendukung penelitiannya melalui orang lain atau dokumen Sugiyono (2013:137). Adapun data sekunder yang penulis gunakan yaitu: studi pustaka, observasi, interview, dan dokumentasi.

\section{Metode Analisis Data}

Data yang diperoleh dari penelitian harus dianalisis terlebih dahulu dengan uji validitas dan realibiltas untuk mengetahui apakah butir-butir pernyataan yang ada sudah memenuhi batas alfa $(\alpha)$. Data diolah dengan menggunakan SPSS 20, tahum 2016. Kemudian dilakukan uji 
asumsi klasik dengan uji normalitas, homogenitas, autokorelasi, multikolinieritas,dan heterokedastisitas. Uji regresi linier sederhana dan berganda serta koefisien determinasi, koefisien korelasiuji t dan uji F (simultan).

Terakhir dilakukan pengujian hipotesis penelitian untuk melihat seberapa besar pengaruh variabel X1 (keselamatan kerja) dan X2 (pelatihan) terhadap Y (kinerja), melalui Uji Parsial T-test dan Uji Simultan F-test.

\section{IV.PEMBAHASAN HASIL PENELITIAN}

\section{A.Gambaran Umum Objek Penelitian}

PT. Aerofood Catering Service berdiri pada tahun 1974. Dimana saat itu perusahaan memulai operasinya dibawah nama PT Aero Garuda Dairy Farm bekerjasama dengan Dairy Farm, sebuah perusahaan catering yang berbasis di HongKong setelah sempat berubah nama menjadi PT Angkasa Citra Sarana Serving, ditahun 1991perusahaan beroperasi dengan bendera ACS (Aerowisata Catering Services). ACS kemudian melakukan diversifikasi dengan menyediakan layanan industrial catering ditahun 2002 dan perusahaan mulai merintis bisnis retail F\&B ditahun 2008. Dengan beragam kesuksesan yang terus diraih, perusahaaan semakin mengembangkan divisi-divisi baru ditahun 2009, yaitu layanan manajemen Laundry dan Infligh Logistic memulai operasinya yang diberi nama Garuda Support.

\section{B. PEMBAHASAN DAN HASIL} 1. Karakteristik Responden

Karakteristik responden meliputi jenis kelamin, usia dan jabatan pekerjaan. Sampel dalam penelitian ini berjumlah 50 responden.

a. Responden berdasarkan jenis kelamin Dari 50 responden menunjukkan bahwa responden dengan berjenis kelamin laki-laki sejumlah 48 orang (96\%), perempuan sejumlah 2 orang (4\%).

b. Responden berdasarkan usia Dari 50 responden menunjukkan bahwa responden yang berusia 18-22 tahun sejumlah 1 orang (2\%), usia 2227 tahun sejumlah33 orang (66\%), usia 27-32 tahun sejumlah 8 orang (16\%), dan usia $\geq 32$ sejumlah8 orang (16\%).

c. Responden berdasarkan lama bekerja Dari 50 responden menunjukkan bahwa responden yang lama bekerja dari 3-6 bulan sejumlah 2 orang (4\%) ,untuk 1-3 tahun sejumlah 18 orang (36\%), untuk 3-5 tahun sejumlah 18 orang (36\%), dan untuk $\geq 5$ sebanyak $12(24 \%)$.

d. Responden berdasarkan pendidikan Dari 50 responden menunjukkan bahwa pendidikan SD sejumlah 2 orang (4\%), untuk SLTPsejumlah5 orang (10\%), untuk SLTAsejumlah 41 orang $(82 \%)$, dan lainyasejumlah2 orang $(4 \%)$. 
JURNAL ILMIAH

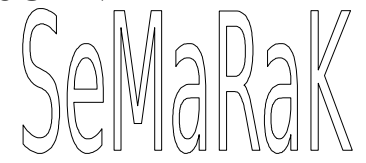

\section{Analisis Deskriptif}

a. Distribusi Responden Keselamatan

Kerja $\left(\mathrm{X}_{1}\right)$

Jawaban dari seluruh responden yang berjumlah 50 orang dengan 4 pertanyaan didapat 46 menjawab " sangat setuju" dengan presentase 23\%, 101 menjawab "setuju" dengan presentase 51\%, 51 menjawab "ragu-ragu" dengan presentase 26\%, 2 menjawab "tidak setuju" dengan presentase $1 \%$ dan tidak ada satupun yang menjawab "sangat tidak setuju". Maka dsimpulkan keselamatan kerja pada PT Aerofood Catering Service cukup baik b. Distribusi Responden Pelatihan $\left(\mathrm{X}_{2}\right)$

Berdasarkan jawaban dari seluruh responden yang berjumlah 50 orang dengan 10 pertanyaan didapat 115 menjawab " sangat setuju" dengan presentase 23\%, 252 menjawab "setuju" dengan presentase $50 \%, 127$ menjawab "ragu-ragu" dengan presentase 25\%, 6 orang menjawab "tidak setuju" dengan presentase $1 \%$ dan tidak ada responden yang menjawab "sangat tidak setuju", Maka dsimpulkan keselamatan kerja pada PT Aerofood Catering Service cukup baik c. Distribusi Responden Kinerja (Y)

Berdasarkan jawaban dari seluruh responden yang berjumlah 50 orang dengan 21 pertanyaan didapat 237 menjawab “ sangat setuju" dengan presentase $23 \%$, 533 menjawab "setuju" dengan presentase
51\%, 269 menjawab "ragu-ragu" dengan presentase $26 \%, 11$ orang menjawab "tidak setuju" dengan presentase $1 \%$ dan tidak ada satupun menjawab "sangat tidak setuju", Maka disimpulkan keselamatan kerja pada PT Aerofood Catering Service cukup baik.

C. Teknik Analisis Data

1. Hasil Uji Validitas

Selanjutnya dilakukan uji validitas untuk menguji indikator pada setiap butir pernyataan pada kuesioner. Dengan dilakukan pengujian ini, maka dapat diketahui keakurasiannya..

a. Uji Validitas Keselamatan Kerja (X1)

Tabel 4.9

Hasil Uji Validitas Variabel

Keselamatan Kerja

\begin{tabular}{|c|c|c|c|}
\hline Pernyataan & Nilai $R$ hitung & Nilai R tabel & keputusan \\
\hline 1 & 0,626 & 0,278 & Valid \\
\hline 2 & 0,733 & 0,278 & Valid \\
\hline 3 & 0,526 & 0,278 & Valid \\
\hline 4 & 0,533 & 0,278 & Valid \\
\hline
\end{tabular}

Sumber : Hasil data olah

Tabel 4.9 di atas menunujukkan, semua item pernyataan variabel pelatihan berada di atas angka 0,278 atau (r hitung $>\mathrm{r}$ tabel), maka semua item dinyatakan valid.

\section{b. Uji Validitas Pelatihan (X2)}

Tabel 4.10

Uji Validitas Variabel Pelatihan

\begin{tabular}{|c|c|c|c|}
\hline Pernyataan & Nilai R hitung & Nilai R tabel & keputusan \\
\hline 1 & 0,551 & 0,278 & Valid \\
\hline 2 & 0,706 & 0,278 & Valid \\
\hline 3 & 0,528 & 0,278 & Valid \\
\hline 4 & 0,518 & 0,278 & Valid \\
\hline 5 & 0,551 & 0,278 & Valid \\
\hline 6 & 0,706 & 0,278 & Valid \\
\hline 7 & 0,528 & 0,278 & Valid \\
\hline 8 & 0,518 & 0,278 & Valid \\
\hline 9 & 0,394 & 0,278 & Valid \\
\hline 10 & 0,542 & 0,278 & Valid \\
\hline
\end{tabular}

Sumber : Hasil data olah 
Data pada tabel 4.10 di atas, semua item pernyataan variabel pelatihan berada di atas angka 0,278 atau (r hitung $>\mathrm{r}$ tabel), maka semua item dinyatakan valid.

c. Uji Validitas Kinerja (Y)

Tabel 4.11

Uji Validitas Variabel Keselamatan Kerja (Y)

\begin{tabular}{|c|r|r|c|}
\hline Pernyataan & Nilai R hitung & Nilai R tabel & keputusan \\
\hline 1 & 0,632 & 0,237 & Valid \\
\hline 2 & 0,735 & 0,237 & Valid \\
\hline 3 & 0,524 & 0,237 & Valid \\
\hline 4 & 0,52 & 0,237 & Valid \\
\hline 5 & 0,632 & 0,237 & Valid \\
\hline 6 & 0,735 & 0,237 & Valid \\
\hline 7 & 0,524 & 0,237 & Valid \\
\hline 8 & 0,52 & 0,237 & Valid \\
\hline 9 & 0,632 & 0,237 & Valid \\
\hline 10 & 0,735 & 0,237 & Valid \\
\hline 11 & 0,524 & 0,237 & Valid \\
\hline 12 & 0,52 & 0,237 & Valid \\
\hline 13 & 0,632 & 0,237 & Valid \\
\hline 14 & 0,735 & 0,237 & Valid \\
\hline 15 & 0,524 & 0,237 & Valid \\
\hline 16 & 0,52 & 0,237 & Valid \\
\hline 17 & 0,632 & 0,237 & Valid \\
\hline 18 & 0,735 & 0,237 & Valid \\
\hline 19 & 0,524 & 0,237 & Valid \\
\hline 20 & 0,52 & 0,237 & Valid \\
\hline 21 & 0,632 & 0,237 & Valid \\
\hline
\end{tabular}

Sumber : Hasil data olah

Data pada tabel 4.11 di atas, semua item pernyataan variabel pelatihan berada di atas angka 0,278 atau ( $\mathrm{r}$ hitung $>\mathrm{r}$ tabel), maka semua item dinyatakan valid.

\section{Uji Reliabilitas}

Uji reliabilitas dimaksudkan untuk menguji kehandalan suatu kuesioner, reliable atau tidak.

\section{a. Uji Validitas Keselamatan Kerja $\left(\mathbf{X}_{1}\right)$}

Tabel 4.12

Hasil Uji Reliabilitas Variabel

Keselamatan Kerja $\left(\mathrm{X}_{1}\right)$

\begin{tabular}{|c|c|}
\hline \multicolumn{2}{|c|}{ Reliability Statistics } \\
\hline $\begin{array}{c}\text { Cronbach's } \\
\text { Alpha }\end{array}$ & N of Items \\
\hline .412 & 4 \\
\hline
\end{tabular}

Sumber : Hasil pengolahan SPSS versi 20
Data tabel 4.12 di atas, diketahui nilai cronbach alpha pada tabel sebesar 0,412. Jadi angka tersebut lebih besar dari angka 0,278 ( $\mathrm{r}$ tabel).

b. Uji Validitas Pelatihan $\left(\mathbf{X}_{2}\right)$

Tabel 4.13

Uji Reliabilitas Variabel Pelatihan $\left(\mathrm{X}_{2}\right)$

\begin{tabular}{|c|c|}
\hline \multicolumn{2}{|c|}{ Reliability Statistics } \\
$\begin{array}{c}\text { Cronbach's } \\
\text { Alpha }\end{array}$ & N of Items \\
\hline .747 & 10 \\
\hline
\end{tabular}

Sumber : Hasil pengolahan SPSS versi 20

Dari data tabel 4.13 di atas, diketahui nilai cronbach alpha pada tabel 4.11 sebesar 0,747. Jadi angka tersebut lebih besar dari angka 0,278 ( $\mathrm{r}$ tabel).

c. Uji Validitas Kinerja (Y)

Tabel 4.14

Uji Reliabilitas Variabel Kinerja (Y)

\begin{tabular}{|r|r|}
\hline $\begin{array}{c}\text { Cronbach's } \\
\text { Alpha }\end{array}$ & N of Items \\
\hline .901 & 21 \\
\hline
\end{tabular}

Sumber : Hasil pengolahan SPSS versi 20

Dari data tabel 4.14 di atas, diketahui nilai cronbach alpha pada tabel sebesar 0,901. Jadi angka tersebut lebih besar dari angka 0,278 ( $\mathrm{r}$ tabel).

2. Hasil Uji Asumsi Klasik a. Uji Normalitas

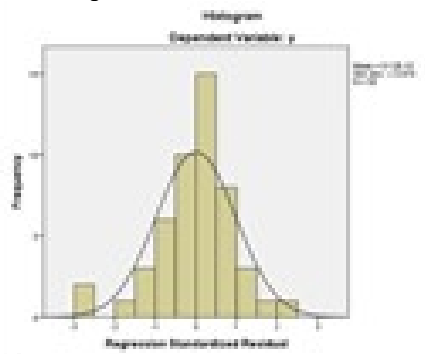

Sumber : Hasil pengolahan SPSS versi 20 Grafik 4.6

Hasil Uji Normalitas Menggunakan Histogram 


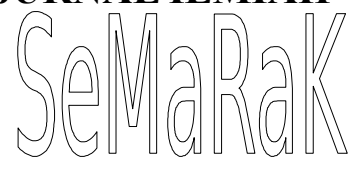

Hasil pengolahan data maka diperoleh grafik Normal P-P Plot of Regression

Strandarized Residual untukvariabel

dependen Kinerja Karyawan.

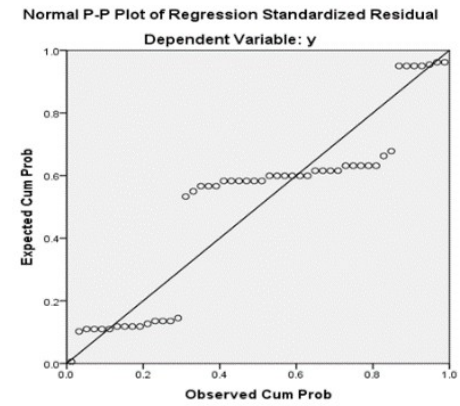

Sumber : Hasil pengolahan SPSS versi 20 Grafik 4.7

Hasil Uji Normalitas

Menggunakan Grafik P-Plot

Dari gambar diatas menunjukkan bahwa terdapat hubungan linear antara variabel independent dan dependent terlihat dari sebaran data mengikuti lurus dari arah kiri ke arah kanan yang artinya memenuhi asumsi normalitas.

\section{b. Uji Autokorelasi}

Tabel 4.15

Hasil Uji Autokorelasi

\begin{tabular}{|c|c|c|c|c|c|}
\hline \multicolumn{6}{|c|}{ Model Summary ${ }^{\mathrm{b}}$} \\
\hline Model & $\mathrm{R}$ & R Square & $\begin{array}{l}\text { Adjusted } \\
\text { R Square }\end{array}$ & \begin{tabular}{|l} 
Std. Error \\
of the \\
Estimate
\end{tabular} & $\begin{array}{l}\text { Durbin- } \\
\text { Watson }\end{array}$ \\
\hline & \begin{tabular}{l|l}
$1.998^{2}$ \\
\end{tabular} & .996 & .996 & .567 & 2.172 \\
\hline $\begin{array}{l}\text { a. Pred } \\
\text { spss } 20\end{array}$ & S1) & t), $x^{2}$ & Sum & $D$ & ah 201 \\
\hline
\end{tabular}

tabel hasil perhitungan nilai Durbin Wat-son pada model adalah sebesar 2.172 dengan demikian bahwa dalam penelitian ini tidak terjadi Autokorelasi.

\section{c. Uji Heterokedastisitas}

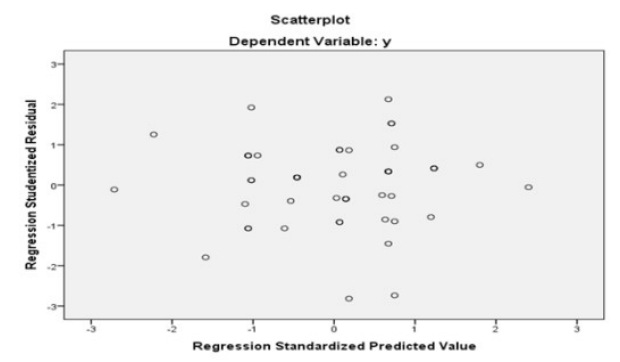

Sumber : Hasil pengolahan SPSS versi 20

Gambar diatas menunjukkan, adanya titik-titik pada grafik scatter plotyang artinya mempunyai pola penyebaran yang jelas. Titik-titik tersebut menyebar ke atas dan kebawah angka 0 pada sumbu Y. maka dapat dsimpulkan jika data dalam penelitian ini tidak ada kesamaan dalam varian dari residual (heterokedastisitas).

\section{d. Uji Multikolinieritas}

Tabel 4.16

Uji Multikolinieritas

\begin{tabular}{|c|c|c|c|c|c|c|c|}
\hline \multicolumn{8}{|c|}{ Coefficients $^{i}$} \\
\hline \multirow{2}{*}{ Model } & \multicolumn{2}{|c|}{$\begin{array}{c}\text { Unstandardized } \\
\text { Coefficients }\end{array}$} & \multirow{2}{*}{\begin{tabular}{|c|}
$\begin{array}{c}\text { Standardized } \\
\text { Coefficients }\end{array}$ \\
Beta \\
\end{tabular}} & \multirow{2}{*}{$t$} & \multirow{2}{*}{ Sig. } & \multicolumn{2}{|c|}{ Collinearity Statistics } \\
\hline & $B$ & $\begin{array}{l}\text { Std. } \\
\text { Error }\end{array}$ & & & & Tolerance & VIF \\
\hline (Constant) & 1.796 & .801 & & 2.242 & .030 & & \\
\hline$\sqrt[1]{\mathrm{x} 1}$ & 4.282 & .156 & .849 & 27.492 & .000 & .089 & 11.265 \\
\hline $\mathrm{x} 2$ & .339 & .067 & .155 & 5.029 & .000 & .089 & 11.265 \\
\hline
\end{tabular}

Sumber : Hasil pengolahan SPSS versi 20

Data tabel diatas memperlihatkan bahwa nilai Variance Inflation Factor (VIF) untuk variable Keselamatan Kerja $\left(\mathrm{X}_{1}\right)$ diperoleh sebesar 11,265 dan Pelatihan $\left(\mathrm{X}_{2}\right)$ diperoleh sebesar 11,265 dimana masing masing nilai tolerance variable bebas kurang dari 1 dan nilai VIF kurang dari 10. Hasil uji ini menunjukantidak ada 
multikolinieritas, yang artinya

model regresi tidak terjadi korelasi

antar variable independen didalam

persamaan itu sendiri.

3. Hasil Uji Koefisien Determinasi

Tabel 4.18

Koefisien Determinasi

\begin{tabular}{|c|c|c|c|c|}
\hline \multicolumn{5}{|c|}{ Model Summary } \\
\hline Model & $\mathrm{R}$ & R Square & $\begin{array}{l}\text { Adjusted } \\
\text { R Square }\end{array}$ & $\begin{array}{l}\text { Std. Error of } \\
\text { the Estimate }\end{array}$ \\
\hline 1 & $.998^{\mathrm{a}}$ & 996 & .996 & .567 \\
\hline
\end{tabular}

a. Predictors: (Constant), $\mathrm{x} 2, \mathrm{x} 1$

Sumber : Hasil pengolahan SPSS versi 20

Data table 4.8menunjukkan nilai

korelasi sebesar 0,996 atau 99,6\%,

artinya dapat ditarik kesimpulan bahwa

variable Keselamatan Kerja $\left(\mathrm{X}_{1}\right)$ dan

Pelatihan $\left(\mathrm{X}_{2}\right)$ terhadap Kinerja $(\mathrm{Y})$

berpengaruh sangat kuat yaitu 99,6\%

sisanya $0,4 \%$ dipengaruhi oleh factor

lain diluar penelitian.

\section{Hasil Pengujian Hipotesis}

a. Uji t

1) $X_{1}$ terhadap $Y$

Tabel 4.19

Uji Korelasi $X_{1}$ terhadap Y

\begin{tabular}{|c|c|c|c|c|c|}
\hline \multicolumn{6}{|c|}{ Coefficients $^{a}$} \\
\hline \multirow[t]{2}{*}{ Model } & \multicolumn{2}{|c|}{$\begin{array}{l}\text { Unstandardized } \\
\text { Coefficients }\end{array}$} & \multirow{2}{*}{\begin{tabular}{|c|}
$\begin{array}{c}\text { Standardized } \\
\text { Coefficients }\end{array}$ \\
Beta
\end{tabular}} & \multirow[t]{2}{*}{$\mathrm{t}$} & \multirow[t]{2}{*}{ Sig. } \\
\hline & $B$ & \begin{tabular}{|l|} 
Std. Error \\
\end{tabular} & & & \\
\hline (Constant) & 3.356 & 906 & & 3.703 & .001 \\
\hline $\mathrm{x} 1$ & 5.029 & .057 & 997 & 88.318 & .000 \\
\hline
\end{tabular}

Sumber : Hasil pengolahan SPSS versi 20

Perolehan hasil data diatas diketahui

persamaan regresi, $t$ hitung dan

signifikan sebagai berikut:

Persamaan Regresi $Y=3.356+5.029 X 1$

$\begin{array}{ll}\text { T hitung } & =88.318 \\ \text { Nilai Signifikan } & =0.000\end{array}$
Berdasarkan temaun diatas maka dapat dikemukakan pengujian hipotesis ini adalah bahwa keselamatan kerja memiliki nilai thitung $(88.318>1.667)$ maka dapat ditarik kesimpulan $\mathrm{Ho}_{1}$ ditolak dan $\mathrm{Ha}_{1}$ diterima. Dengan demikian, maka hipotesis ini telah menjawab rumusan masalah ke-1 yang menyatakan bahwa keselamatan kerja terbukti berpengaruh siginifikan terhadap kinerja.

2) $X_{2}$ terhadap $Y$

Tabel 4.20

Uji Korelasi $\mathrm{X}_{2}$ terhadap Y

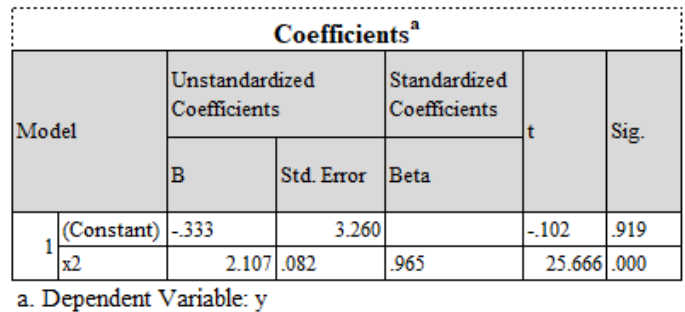

Sumber : Hasil pengolahan SPSS versi 20

Hasil olah data diatas diketahui persamaan regresi, $t$ hitung dan signifikan sebagai berikut:

Persamaan Regresi $\mathrm{Y}=3.333+2.107 \mathrm{X}_{2}$

T hitung $\quad=25.666$

Nilai Signifikan $\quad=0.000$

Berdasarkan temuan diatas maka dapat dikemukakan pengujian hipotesis ini adalah bahwa pelatihan memiliki nilai thitung $(25.666>1.667)$ maka dapat disimpulakn $\mathrm{Ho}_{2}$ ditolak dan $\mathrm{Ha}_{2}$ diterima. Dengan demikian, maka hipotesis ini telah menjawab rumusan 


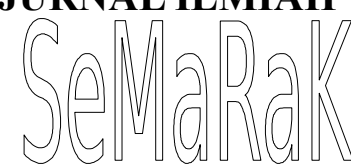

masalah ke-2 yang menyatakan bahwa pelatihan terbukti berpengaruh siginifikan terhadap kinerja.

b. Uji F

Tabel 4.21

Uji Regresi Berganda

\begin{tabular}{|c|c|c|c|c|c|c|c|}
\hline \multicolumn{8}{|c|}{ Coefficients $^{2}$} \\
\hline \multirow{2}{*}{ Model } & \multicolumn{2}{|c|}{$\begin{array}{c}\text { Unstandardized } \\
\text { Coefficients }\end{array}$} & \multirow{2}{*}{\begin{tabular}{|c|}
$\begin{array}{c}\text { Standardized } \\
\text { Coefficients }\end{array}$ \\
Beta \\
\end{tabular}} & \multirow{2}{*}{$\mathrm{t}$} & \multirow{2}{*}{ Sig. } & \multicolumn{2}{|c|}{ Collinearity Statistics } \\
\hline & B & $\begin{array}{l}\text { Std. } \\
\text { Error }\end{array}$ & & & & Tolerance & VIF \\
\hline (Constant) & 1.796 & 801 & & 2.242 & .030 & & \\
\hline$1 \longdiv { x 1 }$ & 4.282 & .156 & .849 & 27.492 & .000 & .089 & 11.265 \\
\hline $\mathrm{x} 2$ & 339 & .067 & .155 & 5.029 & .000 & \begin{tabular}{l|l|l|}
.089 \\
\end{tabular} & 11.265 \\
\hline
\end{tabular}

Sumber : Hasil pengolahan SPSS versi 20

Mengacu pada hasil olah data diatas, maka dapat disimpulkan persamaan regresi linear berganda sebagai berikut: $Y=1,796+4,282 X_{1}+0,339 X_{2}$

Keterangan:

$\mathrm{Y} \quad=$ Kinerja

a $($ konstanta $)=1,796$

$\mathrm{b}($ koefisienregresi $)=$ Variabel kese-

lamatan kerja sebesar 4,282

Variabel pelatihan sebesar 0,339

Persamaan diatas memiliki arti penjelasan sebagai berikut:

1) Bahwa nilai konstanta sebesar 1,796 memiliki arti, meskipun tidak ada pengaruh dari variable keselamatan kerja dan pelatihan, PT Aerofood Catering Service divisi Laundry tetap memiliki kinerja sebesar 1,796

2) Keselamatan kerja terbukti pengaruh positif signifikan terhadap pelatihan yang ditunjukan dari nilai koefisien regresi sebesar 4,282, nilai $\mathrm{t}$ hitung sebesar 27,492 lebih besar dari 2.800 dan nilai sginifikan sebesar 0.000 lebih kecil dari 0.05

3) Pelatihan kerja terbukti berpengaruh positif signifkan terhadap kinerja dalam hal ini dapat ditunjukkan oleh nilai koefisien regresi sebesar 0,339, nilai t htiung sebesar 5.029 lebih besar dari 2.800 dan nilai sginifikan 0,000 lebih kecil dari 0,05.

Tabel 4.21

Uji F Simultan

\begin{tabular}{|l|l|l|r|l|l|l|}
\hline \multicolumn{2}{|l|}{ Model } & $\begin{array}{l}\text { Sum of } \\
\text { Squares }\end{array}$ & df & $\begin{array}{l}\text { Mean } \\
\text { Square }\end{array}$ & F & Sig. \\
\hline \multirow{2}{|l|}{$\begin{array}{l}\text { Regressio } \\
\text { n }\end{array}$} & 3.786 .564 & 2 & 1.893 .282 & 5.886 .727 & $.000^{b}$ \\
\cline { 2 - 6 } & Residual & 15.116 & 47 & 322 & & \\
\cline { 2 - 7 } & Total & 3.801 .680 & 49 & & & \\
\hline
\end{tabular}

a. Dependent Variable: $y$

b. Predictors: (Constant), $x 2, x 1$

Sumber : Hasil pengolahan SPSS versi 20

Dari table diatas diperoleh $\mathrm{F}$ hitung = $5886,727>2,800$ atau $(\mathrm{F}$ hitung $>\mathrm{F}$ table) dan nilai signifikan sebesar 0.000 lebih kecil 0.05, maka dapat dsimpulkan $\mathrm{Ho}_{3}$ ditolak $\mathrm{Ha}_{3}$ diterima. Artinya terdapat pengaruh positif dan simultan antara Keselamatan Kerja dan Pelatihan terhadap Kinerja.

\section{V.KESIMPULAN DAN SARAN}

\section{A. Kesimpulan}

Setelah dilakukan mengenai penelitian tentang "Pengaruh Keselamatan Kerja dan Pelatihan terhadap Kinerja pada PT Aerofood Catering Service Divisi Laundry", maka dapat ditarik beberapa kesimpulan yaitu sebagai berikut : 
JURNAL ILMIAH

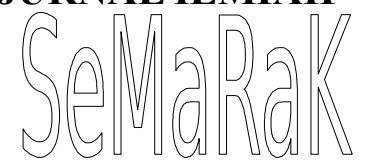

1. Dari hasil analisis regresi linear sederhana menandakan bahwa keselamatan kerja berpengaruh signifikan terhadap kinerja dengan nilai $\mathrm{t}$ hitung sejumlah 88.318, nilai signifikasi sejumlah 0.000 , nilai koefisien regresi sejumlah 5.029 dan persamaan regresi $\mathrm{Y}=3.356+5.029 \mathrm{X}_{1}$.

Nilai R (korelasi) adalah 0,994 dan nilai R Square (determinasi) adalah 0,997, menunjukkan bahwa variable Y (kinerja karyawan) dipengaruhi oleh $\mathrm{X}_{1}$ (keselamatan kerja) sebesar 99,7\% dan sisanya $0,3 \%$ dipengaruhi oleh faktorfaktor lain yang tidak diteliti.

2. Hasil analisis regresi linear sederhana menunjukan bahwa pelatihan berpengaruh signifikan terhadap kinerja dengan nilai $\mathrm{t}$ hitung sebesar 25.666, nilai signifikansi sebesar 0.000, nilai koefisien regresi sebesar 2.107 dan persamaan regresi linear $\mathrm{Y}=3.333+2.107 \mathrm{X}_{2}$

Nilai R (korelasi) adalah 0,962 dan nilai $R$ Square (determinasi) 0,935, menandakan bahwa variable Y (kinerja karyawan) dipengaruhi oleh $\mathrm{X}_{2}$ (pelatihan) sejumlah $96,5 \%$ dan sisanya $3,4 \%$, pengaruh daripenyebab (faktor) lain yang tidak diteliti.

3. Hasil uji regresi linear berganda megindikasikan bahwa keselamatan kerja dan pelatihan secara bersamaan berpengaruh signifikan terhadap kinerja dengan nilai $\mathrm{F}$ hitung 27.492, nilai signi- fikansi 0.000 , nilai koefisien determinasi sejumlah 0.996 dan persamaan regresi linear $\mathrm{Y}=1,796+4,282 \mathrm{X}_{1}+0,339 \mathrm{X}_{2}$.

\section{B. Saran}

Dengan kesimpulan pembahasan yang diuraikan di atas, maka disampaikan saran-saran dari penelitian adalah :

1. Untuk lebih baik lagi perusahaan meningkatkan kualitas materi tentang keselamatan kerja dan pelatihan sehingga sesuai dengan tujuan yang ingin dicapai dan para karyawan dapat merasakan manfaat keselamatan kerja dan pelatihan tersebut untuk meningkatkan kinerja mereka. Hal ini tercermin dari jawaban responden yang masih belum optimal. Dari 2\% jawaban responden menyatakan perusahaan harus menyediakan peralatan yang memadai dan bias dapat merasakan manfaat Keselamatan Kerja dan Pelatihan dalam meningkatkan kinerja.

2. Agar kedepannya lebih baik lagi, karyawan perlu meningkatkan rasa tanggung jawab, ketelitian dan kecepatan serta kemampuan dalam menyelesaikan tugas dengan cara memberikan pelatihan yang diberikan oleh perusahaan.Dari 2\% jawaban responden diketahui bah-wa penyampaian materi pelatihan harus lebih detail agar karyawan dapat memahami tujuan dari pelatihan tersebut. 
3. Pengaruh Keselamatan Kerja $\left(\mathrm{X}_{1}\right)$ dan Pelatihan $\left(\mathrm{X}_{2}\right)$ terhadap Kinerja $(\mathrm{Y})$ sebesar $99,6 \%$, sisanya $0,4 \%$ di pengaruhi oleh (penyebab) faktor lain, menunjukkan bahwa kondisi variabel independen harus ditingkatkan secara signifikan,Dengan demikian disarankan kepada peneliti selnajutnya agar melakukan research yang terkait, dengan cara memperbaiki indikator yang masih kurang tepat atau dengan menambah sub indikator pernyataan, menambah jumlah responden penelitian atau bisa juga dengan menambah jumlah variabel bebas yang sesuai.

\section{DAFTAR PUSTAKA}

Bangun, Wilson. (2012). Manajemen Sumber Daya Manusia. Bandung: Erlangga.

Darsono Dan Tjatjuk, Siswandoko, 2011, Manajemen Sumber Daya Manusia Abad 21, Nusantara Consulting, Jakarta

Drucker, Peter F. (2008), Pengantar Manajemen.Jakarta Pustaka Binaman Pressindo,Effendi.

Gomes, Faustino Cardoso. (2003). Manajemen Sumber Daya Manusia.Yogyakarta. Penerbit Andi.

Fitri, Yunita S. (2010). Manajemen Personalia dan Sumber Daya Manusia. Yogyakarta: BPFE.

Hasibuan, Malayu. (2017). Manajemen Sumber Daya Manusia.Edisi Revisi. Jakarta: PT. Bumi Aksara.
Handoko, Hani. (2014). Manajemen Personalia dan Sumber Daya Manusia.Yogyakarta: BPFE UGM.

Krisnaldy, K., Pasaribu, V. L. D., \& Senen, S. (2019). PENGARUH BUDAYA ORGANISASI, LINGKUNGAN KERJA DAN IKLIM ORGANISASI TERHADAP MOTIVASI PEGAWAI SERTA DAMPAKNYA TERHADAP KEPUASAN KERJA. Jurnal Semarak, 2(2).

L. Mathis, R. H. (2011). Human Resource Management (Manajemen Sumber Daya Manusia). Jakarta: Salemba Empat.

L. Mathis, R. H. (2011). Evaluasi Kinerja SDM. Jakarta: Salemba Empat.

Mangkunegara, Anwar Prabu. (2013). Manajemen Sumber Daya Manusia Perusahaan. Bandung: Remaja Rosdakarya.

Moekijat. (2010). Manajemen Sumber Daya Manusia. Bandung: Mandar Maju.

Mangkuprawira, Sjafri. (2011). Manajemen Sumber Daya Manusia Strategik. Bogor: Ghalia Indonesia.

Notoatmodjo, S. (2009). Pengembangan Sumber Daya Manusia. Jakarta : Rineka Cipta.

Robbins SP, dan Judge (2005). Perilaku Organisasi ed 12.Jakarta: Salemba.

Samsudin, H, Sadeli. (2010). Manajemen Sumber Daya Manusia. Bandung: Pustaka Setia. 


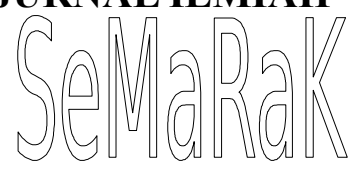

Sarinah dan Mardalena. (2017). Pengantar Manajemen. Yogyakarta: CV. Budi Utama.

Siagian. (2011). Manajemen Sumber Daya Manusia. Jakarta: PT. Bumi Aksara.

Sugiyono. (2013). Statistika Untuk Penelitian.Bandung: Alfabeta.

Sutrisno, Edi. (2013). Manajemen Sumber Daya Manusia. Jakarta: Kencana Prenana Media Group.

Triton. PB. (2010). Manajemen Strategis : Terapan Perusahaan dan Bisnis. Yogyakarta : Tugu Publisher .

\section{Sumber Jurnal:}

Artawijaya, I.G.P.A,.and Darma, G.S. 2015. Evaluation The Effectivity of Performance Management Online System to Improving The Employees Performance.12 (2): h:73-89. Jurnal Manajemen dan Bisnis

Dwihatmojo. 2016. Rekrutmen, Pelatihan, dan Pembagian Kerja engaruhnya terhadap Kinerja Karyawan pada C. Jati Jaya Meubel Amurang.4(1). Jurnal EMBA

Effendi. S. 2014. Pengaruh Seleksi dan Pelatihan terhadap Kompetensi serta Dampaknya pada Kinerja Karyawan.9(17). Jurnal Manajemen dan Bisnis Aliansi

Purnantara, I.M.H., and Darma, G.S. 2015.Comptenecy, Organizational Health, Job Career, Job Performance and Employees Turnover. 12(2): h: 90-124. Jurnal Manajemen dan Bisnis.

Pasaribu, V. L. D., \& Krisnaldy, K. (2018). ANALISIS KEPUASAN JAMA'AH PADA KINERJA DEWAN KEMAKMURAN MASJID AL-HIDAYAH PERIODE TAHUN 2017. KREATIF: Jurnal Ilmiah Prodi Manajemen Universitas Pamulang, 6(4), 41-51. 